\title{
Parry-Romberg Syndrome: a Rare Case Report
}

\author{
Anusha Laxman Rangare', Subhas Gogineni Babu' ${ }^{1}$, Priya Sara Thomas ${ }^{1}$, Shishir Ram Shetty ${ }^{1}$ \\ 'Department of Oral and Maxillofacial Radiology, AB Shetty Memorial Institute of Dental Sciences, Nitte University, \\ Deralakatte, Mangalore, Karnataka, India.
}

\author{
Corresponding Author: \\ Anusha Laxman Rangare \\ Department of Oral Medicine and Radiology \\ AB Shetty Memorial Institute of Dental Sciences \\ Nitte University, Deralakatte, Mangalore 575018, Karnataka \\ India \\ Phone: +919986787113 \\ E-mail: renita.castelino@yahoo.com
}

\begin{abstract}
Background: The purpose of this report is to present a rare entity of Parry-Romberg syndrome. This poorly understood degenerative condition is characterised by atrophic changes affecting one side of the face. The cause of these changes remains obscure.

Methods: The authors report one rare case of a 31 year old female patient with Parry-Romberg syndrome, accompanied by a brief review of literature.

Results: Clinical examination of the patient revealed evident facial asymmetry, malar hypoplasia, atrophy of skin and other tissues on the left side, hyperpigmentation of skin on the left side of the face. Final diagnosis of a Parry-Romberg syndrome ("progressive hemifacial atrophy") was based on thorough clinical and a radiological examination. Treatment using alloplastic implants to improve facial disfigurement was suggested to the patient.

Conclusions: In most cases, Parry-Romberg syndrome appears to occur randomly for unknown reasons. The pathophysiology of the syndrome remains unknown. There is no definitive treatment for this condition but an attempt to use restorative plastic surgery which includes fat or silicone implants, flap/pedicle grafts, or bone implants can be done to improve facial disfigurement.
\end{abstract}

Keywords: progressive hemifacial atrophy; Parry-Romberg syndrome; Romberg's disease; Romberg hemi-facial atrophy; mouth diseases; enophthalmos.

\author{
Accepted for publication: 30 March 2011 \\ To cite this article: \\ Rangare RA, Babu GS, Thomas PS, Shetty RS. Parry-Romberg Syndrome: a Rare Case Report. \\ J Oral Maxillofac Res 2011 (Apr-Jun);2(2):e5 \\ URL: http://www.ejomr.org/JOMR/archives/2011/2/e5/v2n2e5ht.pdf \\ doi: $10.5037 /$ jomr.2011.2205
}




\section{INTRODUCTION}

Parry-Romberg syndrome (PRS) also known as "progressive facial hemiatrophy" is characterized by a progressive but self-limited atrophy of the skin and subcutaneous tissue on one side of the face $[1,2]$. PRS was first reported by Parry and then described as a syndrome by Romberg $[\underline{3}, \underline{4}]$. There is a progressive wasting of subcutaneous fat, sometimes accompanied by the atrophy of skin, cartilage, bone, and muscle [ $\underline{5}$ ]. It overlaps with a condition known as linear scleroderma "en coup de sabre" [] $]$. In most of the instances atrophy is usually confined to one side of the face and cranium; however it may occasionally spread to the neck and one side of the body $[\underline{7}, 8]$. The onset is insidious and the condition usually manifests in the first or the second decade of life with skin changes resembling scleroderma $[\underline{9}, \underline{10}]$. Progression of the disease is rapid in the two to ten years following onset and then stabilizes [2]. It is usually accompanied by neurological complications like trigeminal neuralgia, migraine, seizures and changes in the eyes and hair [11-13]. Partial seizures have found to be most common neurological complication [14]. In a survey conducted worldwide $11 \%$ of the patients with PRS had coexistent epilepsy [15]. The aetiology of this condition is unclear $[16,17]$. Many theories have been postulated to explain this rare disease like autoimmunity, trigeminal theory and etc [2]. Hemifacial atrophy occurs sporadically and some familial distribution has been found [18]. The disease is common in females and the male to female ratio is $3: 2$ [5]. Ocular involvement is common and the most frequent manifestation is enophthalmos [19]. There are no published trials of the treatment, however the restorative plastic surgery which includes fat or silicone implants, flap/pedicle grafts, or bone implants can be used $[\underline{6}, \underline{20}]$. Radiographically, the teeth on the involved side appear small and usually have short roots [21].

Authors herein present a case of a rare and an uncommon case of Parry-Romberg syndrome.

\section{CASE DESCRIPTION AND RESULTS}

A 31 year old female patient reported to the Department of Oral Medicine and Radiology, AB Shetty Memorial Institute of Dental Sciences, Nitte University, Deralakatte, Mangalore, Karnataka, India, with the complaint of multiple root stumps in the maxillae and the mandible since six months. There were no associated symptoms. The patient's medical and family history was non contributory.
On general, a physical examination facial asymmetry was detected due to the hollowing of cheek and chin on the left side (Figure 1), the left eye was depressed in the socket (enophthalmos) along with deficient eyebrows (Figure 2), the malar hypoplasia, atrophy of facial skin and upper lip on the left side. Loss of the subcutaneous fat with prominent bony ridges on the ipsilateral side was observed when compared to the normal side. (Figures $3 \mathrm{~A}$ and $3 \mathrm{~B}$ ). There was a deviation of nose and the angle of mouth to the affected side. Pigmentation was noticed on the left side of the forehead and the chin region. Scant hair and eyebrows were present on the left side. There was a atrophy of temporalis, buccinator, masseter muscles and prominent zygomatic arch on the left side (Figure 4). The ear on the left side was pulled towards the front giving it a bat ear appearance.

On the further evaluation patient gave a history of trauma (fall) from approximately 4 - 5 feet above the ground, when the patient was six months old.

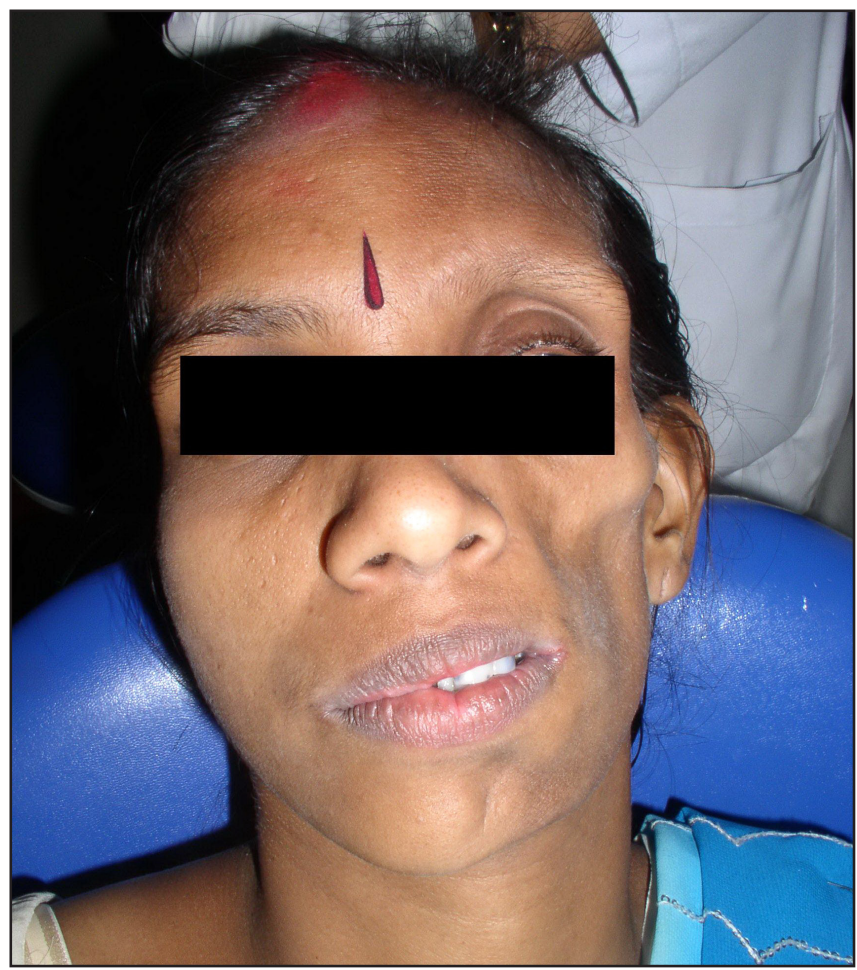

Figure 1. Clinical photograph showing marked asymmetry of the face.

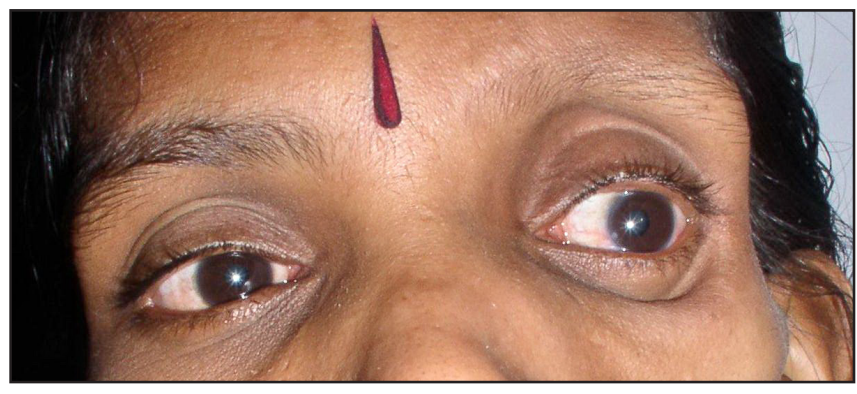

Figure 2. Clinical photograph showing enophthalmos. 


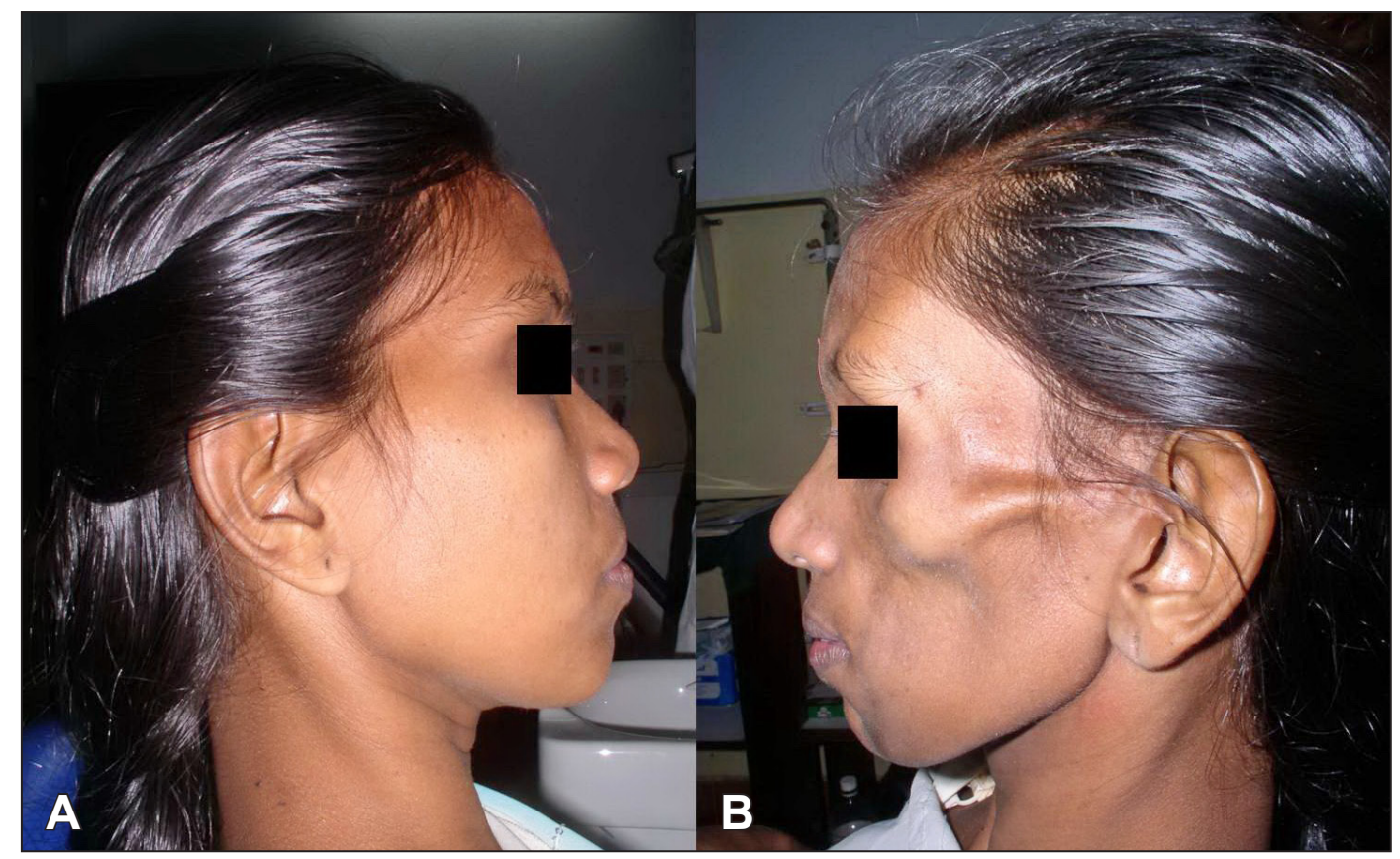

Figure 3. Comparison of the normal and the abnormal side. $\mathrm{A}=$ normal side $\mathrm{B}=$ abnormal side .

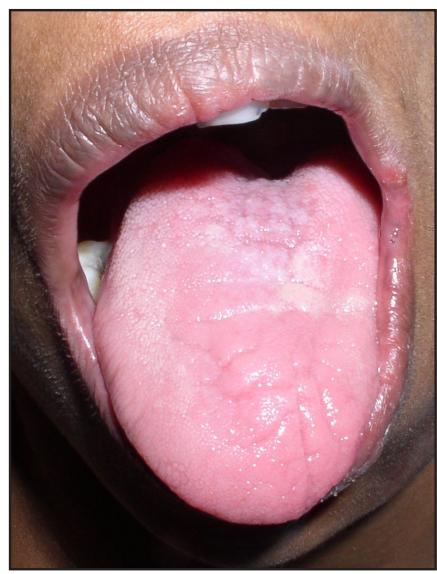

Figure 4. Clinical photograph showing atrophy of the left side of the tongue.

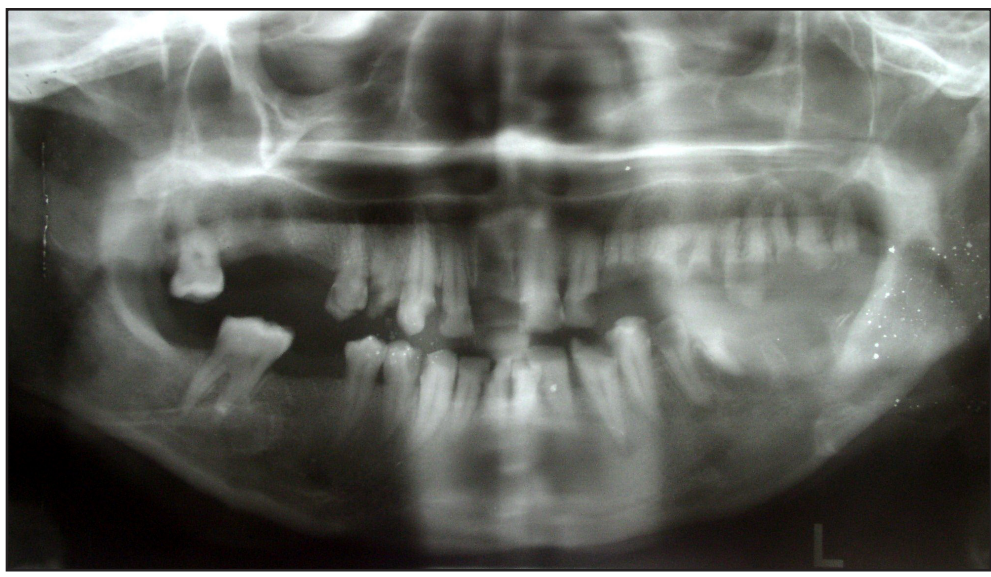

Figure 6. Orthopantomography showing thinning of the body of mandible, smaller condyle and the coronoid process, shorter roots of teeth on the left side when compared to the right side.

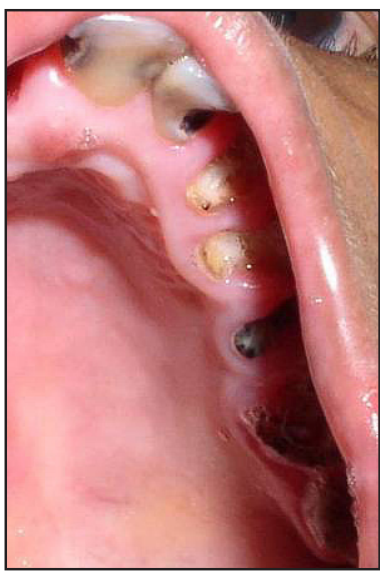

Figure 5. Clinical photograph showing multiple root stumps and decayed teeth.

The patient also noticed brownish discoloration of the skin near the forehead followed by shrinkage of the left side of the face when she was thirteen years of age. The patient visited a local physician, who suggested cosmetic correction for the same, but could not carry out the treatment because of financial reasons.

The intraoral examination revealed the atrophy of tongue on the left side and angular cheilitis on the same side. Maxilla and mandible appeared hypoplastic on the affected side. The teeth examination revealed multiple root stumps and decayed teeth (Figure 5).

Based on the clinical features, a diagnosis of ParryRomberg syndrome was made. Routine blood investigations were carried out which revealed all values within normal limits.

As a part of radiographic investigations an orthopantomogram, paranasal sinuses view and a posterior-anterior cephalogram was made. The orthopantomogram revealed thinning of the body of mandible, smaller condyle and the coronoid process, shorter roots of teeth on the left side, when compared to the right side (Figure 6).

The paranasal sinus $\mathrm{x}$-ray examination showed smaller frontal and maxillary sinus on the left side when compared to the right side (Figure 7).

The posterior-anterior cephalograms revealed asymmetry of the jaws (Figure 8).

As a part of treatment all the teeth of fewer prognoses were extracted and a removable partial denture was fabricated. 


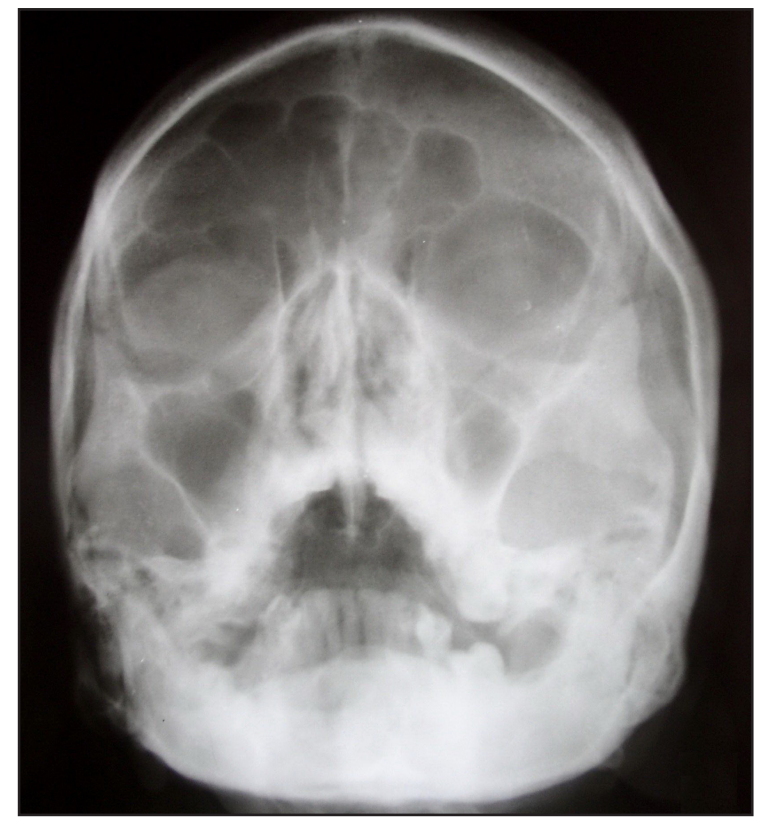

Figure 7. Paranasal sinuses radiograph showing hypoplastic maxillary sinus on the left side when compared to the right side.

There is no definitive treatment for this condition but an attempt to use alloplastic implants can be done to improve facial disfigurement. Similar treatment was suggested to the patient, but the patient could not make it up for a logistic reasons. The patient was reviewed for a period of six months and no progressive changes have occurred.

\section{DISCUSSION}

PRS is an uncommon degenerative and poorly understood condition [21]. It is characterized by a slow and progressive unilateral atrophy of the facial tissues, including muscles, bones and skin $[\underline{22}, \underline{23}]$. The condition is more often found in female population and has predilection for the left side of the face, which is seen in presented herein case [5]. More than an aesthetic concern, this disease brings several functional and psychological problems due to asymmetry of the face [21]. The main feature is hemiatrophy of the facial tissues, typically fat, but variably skin, other connective tissue, and sometimes bone [6]. All these features were present in the case herein. The prevalence rate is estimated to be at least 1 per 700.000 in the general population [6]. Characteristically, the atrophy progresses slowly during many years and then becomes stable as in our case [23-25].

The extension of atrophy is frequently limited to on one side of the face, and the ipsilateral involvement of body is rare (23 to $10 \%$ of cases were described as being bilateral) [9]. In the case presented here, there was involvement of only one side of the face. The most

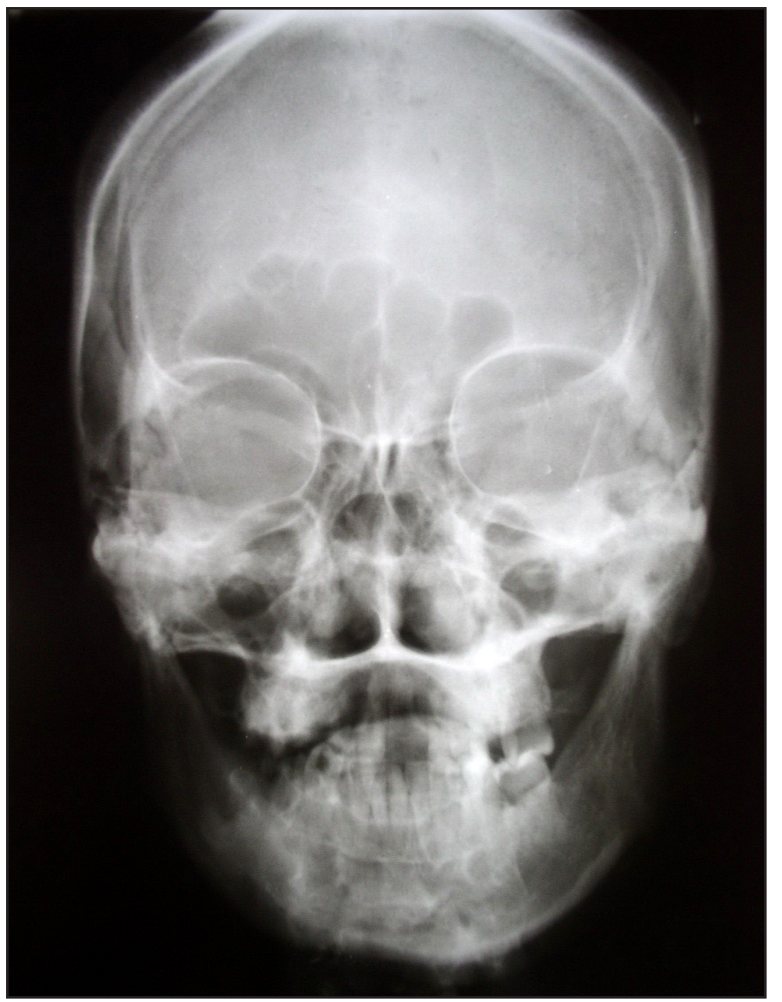

Figure 8. Posterior-anterior cephalogram showing asymmetry of the jaws.

important features of this disease are enophthalmos, the deviation of mouth and nose to the affected side, and the unilateral exposition of teeth (when lips are involved) [26], which were also found in our case. Clinically, the skin can be dry and hyperpigmented [21], which is also seen in presented case. Some patients present a demarcation line between normal and abnormal skin, known as "coup de sabre" (French term which means "cut of the sword") [으, 211] which is not seen in our case. Another important feature is ocular involvement and the most frequent manifestation is the enophthalmos, due to fat loss around the orbit, as was observed in our patient $[11-13,21,27]$. Thinning of the ear due to atrophy of the fat around it, alopecia on the involved side was a manifestation registered in our patient [21]. The neurological complications, such as trigeminal neuralgia, facial paresthesia, severe headache and contralateral epilepsy can also be present [11-14], but were not diagnosed in our case. Our patient also presented with atrophy of the tongue on one side in consistent with the findings mentioned by Da SilvaPinheiro TP et al. [21]. Our case showed all the classical clinical manifestations of the disease.

Radiographically, the teeth of patients with PRS have short roots and appear small, when compared to the uninvolved side [21]. The similar findings were present in our case (Figure 6). Unilateral crossbite can be present due to hypoplasia of bone and delayed eruption. These features could not be seen as the patient had multiple 
root stumps on the affected side (Figure 5).

The treatment is usually based on reposition of adipose tissue that was lost due to atrophy. Autogenous fat grafts, cartilage grafts, silicon injections and prostheses, bovine collagen and inorganic implants are some alternatives to aesthetic correction of the atrophy [28]. The treatment modalities mentioned, resolve just momentarily the good appearance, whereas all the structure projected in the cosmetic surgery is lost with time, due to gravity action, and the patient usually requires new intervention [21]. Panfacial volumisation with autologous fat is an excellent tool for replacing volume and restoring contour to the aging face [29]. Our patient was suggested treatment using alloplastic implants to improve the facial appearance, but could not make up for financial and logistical reasons.

\section{CONCLUSIONS}

Parry-Romberg syndrome is an uncommon condition, which manifest as atrophy of one side of the face. In most cases, Parry-Romberg syndrome appears to occur randomly for unknown reasons. The pathophysiology of the syndrome remains unknown. We hereby are presenting a case of Parry-Romberg syndrome with classical features.

\section{ACKNOWLEDGMENTS AND DISCLOSURE STATEMENTS}

The authors report no conflicts of interest related to this study.

\section{REFERENCES}

1. Padmini P, Singhi PD. Facial hemiatrophy. Indian Pediatr. 1992 Apr;29(4):505-7. [Medline: 1506105]

2. Gulati S, Jain V, Garg G. Parry Romberg syndrome. Indian J Pediatr. 2006 May;73(5):448-9. [Medline: 16741338] [doi: 10.1007/BF02758576]

3. Parry CH. Collection From the Unpublished Medical Writings of the Late Calet Hillier Parry. London, England: Underwoods; 1825:478.

4. Romberg MH. Trophoneurosen Kliniske Ergenbrisse. Berlin, Germany: Forster; 1846:75-81.

5. Rogers BO. Progressive facial hemiatrophy: Romberg's disease: a review of 772 cases. Proc $3 d$ Int Cong Plast Surg. Excerpta Medica ICS. 1964;66:681-689.

6. Stone J. Parry Romberg syndrome. Practical Neurology 2006; 6: 185-188. [doi: 10.1136/jnnp.2006.089037]

7. Rogers BO: Embryology of the face and introduction to craniofacial anomalies. In: Converse JM editor. Reconstrucfive Plastic Surgery, 2nd ed. WB Saunders, Philadelphia; 1977. p. 2296-2358.

8. Hickman JW, Sheils WS. Progressive facial hemiatrophy. Report of a case with marked homolateral involvement. Arch Intern Med. 1964 May;113:716-20.9. [Medline: 14120599]

9. Miller MT, Spencer MA. Progressive hemifacial atrophy. A natural history study. Trans Am Ophthalmol Soc. 1995; 93:203-15; discussion 215-7. [Medline: 8719679] [FREE Full Text]

10. Mendonca J, Viana SL, Freitas F, Lima G. Late-onset progressive facial hemiatrophy (Parry-Romberg syndrome). J Postgrad Med. 2005 Apr-Jun;51(2):135-6.11. [Medline: 16006711]

11. Sagild JC, Alving J. Hemiplegic migraine and progressive hemifacial atrophy. Ann Neurol. 1985 Jun;17(6):620. [Medline: 4026238] [doi: 10.1002/ana.410170621]

12. Chbicheb M, Gelot A, Rivier F, Roubertie A, Humbertclaude V, Coubes P, Echenne B. [Parry-Romberg's syndrome and epilepsy]. Rev Neurol (Paris). 2005 Jan;161(1):92-7. French. [Medline: 15678008] [doi: 10.1016/S0035-3787(05)84980-X]

13. Haldar A, Mukherjee A. Parry Romberg's disease with intractable partial epilepsy. Neurol India. 2007 Apr-Jun;55(2):160-2. [Medline: 17558124] [doi: 10.4103/0028-3886.32791]

14. Asher SW, Berg BO. Progressive hemifacial atrophy: report of three cases, including one observed over 43 years, and computed tomographic findings. Arch Neurol. 1982 Jan;39(1):44-6. [Medline: 7055447]

15. Stone J. Parry-Romberg syndrome: a global survey of 205 patients using the Internet. Neurology. 2003 Sep 9;61(5):674-6. [Medline: 12963760]

16. Davis WB. Reconstruction of hemiatrophy of face. Case report. Plast Reconstr Surg. 1968 Nov;42(5):489-91. [Medline: 4880839] [doi: 10.1097/00006534-196811000-00020]

17. Hakin KN, Yokoyama C, Wright JE. Hemifacial atrophy: an unusual cause of enophthalmos. Br J Ophthalmol. 1990 Aug;74(8):496-7. [Medline: 2390527] [FREE Full Text] [doi: 10.1136/bjo.74.8.496]

18. Witkop CJ. Genetic disease of the oral cavity: In Teiecke RW editor. New York, Mcgrant Hill 1965.

19. Kumar AA, Kumar RA, Shantha GP, Aloogopinathan G. Progressive hemi facial atrophy - Parry Romberg syndrome presenting as severe facial pain in a young man: a case report. Cases J. 2009 Jul 2;2:6776. [Medline: 19829858] [FREE Full Text] [doi: 10.4076/1757-1626-2-6776] 
20. Iñigo F, Jimenez-Murat Y, Arroyo O, Fernandez M, Ysunza A. Restoration of facial contour in Romberg's disease and hemifacial microsomia: experience with 118 cases. Microsurgery. 2000;20(4):167-72. [Medline: 10980515] [doi: 10.1002/1098-2752(2000)20:4<167::AID-MICR4>3.0.CO;2-D]

21. Pinheiro TP, Silva CC, Silveira CS, Botelho PC, Pinheiro MG, Pinheiro Jde J. Progressive Hemifacial Atrophy--case report. Med Oral Patol Oral Cir Bucal. 2006 Mar 1;11(2):E112-4. Review. [Medline: 16505785] [FREE Full Text]

22. Jurkiewicz MJ, Nahai F. The use of free revascularized grafts in the amelioration of hemifacial atrophy. Plast Reconstr Surg. 1985 Jul;76(1):44-55. [Medline: 4011779] [doi: 10.1097/00006534-198507000-00007]

23. Lakhani PK, David TJ. Progressive hemifacial atrophy with scleroderma and ipsilateral limb wasting (Parry-Romberg syndrome). J R Soc Med. 1984 Feb;77(2):138-9. [Medline: 6737396] [FREE Full Text]

24. Moore MH, Wong KS, Proudman TW, David DJ. Progressive hemifacial atrophy (Romberg's disease): skeletal involvement and treatment. Br J Plast Surg. 1993 Jan;46(1):39-44. [Medline: 8431740] [doi: 10.1016/0007-1226(93)90063-H]

25. Roddi R, Riggio E, Gilbert PM, Hovius SE, Vaandrager JM, van der Meulen JC. Clinical evaluation of techniques used in the surgical treatment of progressive hemifacial atrophy. J Craniomaxillofac Surg. 1994 Feb;22(1):23-32. [Medline: 8175994] [doi: 10.1016/S1010-5182(05)80292-6]

26. Pensler JM, Murphy GF, Mulliken JB. Clinical and ultrastructural studies of Romberg's hemifacial atrophy. Plast Reconstr Surg. 1990 May;85(5):669-74; discussion 675-6. [Medline: 2326349] [doi: 10.1097/00006534-199005000-00001]

27. Muchnick RS, Aston SJ, Rees TD. Ocular manifestations and treatment of hemifacial atrophy. Am J Ophthalmol. 1979 Nov;88(5):889-97. [Medline: 507167]

28. 28. de la Fuente A, Jimenez A. Latissimus dorsi free flap for restoration of facial contour defects. Ann Plast Surg. 1989 Jan;22(1):1-8. [Medline: 292340229] [doi: 10.1097/00000637-198901000-00001]

29. Donofrio LM. Panfacial volume restoration with fat. Dermatol Surg. 2005 Nov;31(11 Pt 2):1496-505. [Medline: 16416631] [doi: 10.2310/6350.2005.31234]

\section{To cite this article:}

Rangare RA, Babu GS, Thomas PS, Shetty RS. Parry-Romberg Syndrome: a Rare Case Report.

J Oral Maxillofac Res 2011;2(2):e5

URL: http://www.ejomr.org/JOMR/archives/2011/2/e5/v2n2e5ht.pdf

doi: $\underline{10.5037 / j o m r .2011 .2205}$

Copyright (C) Rangare RA, Babu GS, Thomas PS, Shetty RS. Accepted for publication in the JOURNAL OF ORAL \& MAXILLOFACIAL RESEARCH (http://www.ejomr.org/), 30 March 2010.

This is an open-access article, first published in the JOURNAL OF ORAL \& MAXILLOFACIAL RESEARCH, distributed under the terms of the Creative Commons Attribution-Noncommercial-No Derivative Works 3.0 Unported License, which permits unrestricted non-commercial use, distribution, and reproduction in any medium, provided the original work and is properly cited. The copyright, license information and link to the original publication on (http://www.ejomr.org/) must be included. 